37. The current situation in Turkey. Central Intelligence Agency. ORE 50, 20 October 1947 (1947). [Online]. - Available from: http://www.foia.cia.gov/docs/DOC_0000256623/DOC_0000256623.pdf [Accessed: 19th June, 2017].

Надійшла до редколегії 02.10.2017

Nikolai Saychuk, Ph.D. (history), Board member of the Ukrainian Association for American Studies.

\title{
THE BLACK SEA BASIN IN THE OPERATIONAL AND STRATEGIC PLANNING OF THE US ARMED FORCES DURING THE COLD WAR
}

Abstract. This article describes the importance of the Black Sea basin and the Black Sea Straits in the operational and strategic planning of the US Armed Forces during the Cold War. Initially the Black Sea region was considered one of the two main axis of American strategic offensive against the USSR in Europe. But in the 1960s, as a result of the deployment of the Soviet navy in the Mediterranean Sea and the overall reinforcement of the Soviet Army, the Black Sea Basin was closed to the US and NATO Armed Forces. US planners now opted for a strategic defense in the Black Sea Strait zone. Operations in the Black Sea basin were allowed only at the second or third stages of the war after achieving decisive success in the Central Europe and defeating SovietBulgarian forces in the Balkans. Due to the inability of the Turkish forces to defend the Black Sea Straits by themselves, strong US reinforcements of this area were planned.

In the early 1980s, as the US Armed Forces were approached the technical superiority over the Soviet Army in conventional weapons, the US command returned to the concept of the offensive operations in the Black Sea basin. The beginning of the development of new operational concepts begun with the regular conduct of the so-called "Black Sea Ops" - the operational patrols of the US Sixth Fleet in the Black Sea.

Keywords: the USA, the USSR, the Black Sea, the Black Sea Straits, NATO, Warsaw Pact.

УДК 327 (73) «2017»

http://doi.org/10.17721/2521-1706.2018.04.76-84
Олександр Шевчук, доктор політичних наук, професор, декан факультету політичних наук, Чорноморський національний університет ім. Петра Могили, м. Миколаїв

\section{ПОЗИЦІОНУВАННЯ США НА МІЖНАРОДНІЙ АРЕНІ ЗА ПРЕЗИДЕНСТВА Д. ТРАМПА: ГЛОБАЛЬНИЙ ТА РЕГІОНАЛЬНИЙ ВИМІРИ}

\begin{abstract}
Анотація. У статті проаналізовано можливі иляхи трансформації зовнішньополітичної стратегї США за президентства Д. Трампа. Наразі зовнішньополітична доктрина нової республіканської адміністраиї̈ знаходиться у стані розробки. Зважаючи ж на практичний вимір дій адміністрачії президента США Д. Трампа на міжнародній арені можна протежити формування основних вимірів та меж втілення зовнішньополітичної стратегії: 1. Протиборство з ісламським тероризмом, зокрема Ісламською державою й міжнародним тероризмом в різноманітних формах $i$
\end{abstract}


виявах. 2. Відносини з КНР. Дї̈ офіиійного Пекіна у економічній сфері зазнали жорсткої критики з боку новообраного президента ще під час виборчої кампанії. Однією 3 детермінант американсько-китайських відносин $\epsilon$ позищія США щуодо ролі КНР у врегулюванні північнокорейської проблеми. 3. Змістовне наповнення відносин $з$ європейськими союзниками. У своєму виступі на Брюсельському саміті НАТО, який відбувся 25-26 травня 2017 президент США Д. Трамп заявив лідерам країн НАТО, шо вони повинні збільшити свої оборонні витрати як мінімум до 2\% ВВП, тоді як зараз лише n'ять з 28 членів альянсу виконують ие зобов'язання. Крім того, лідер США неодноразово висловлювався проти планованого укладення угоди про вільну торгівлю між США $і$ ЄС Трансатлантичного торгівельного та інвестииійного партнерства. 4. Характер еолюиіі відносин між Вашингтоном і Москвою. Точками «накалу» у американсько-російських відносинах є проблема Сирії, українське питання, позиція Росії щэодо санкиій відносно КНДР тошчо.

Ключові слова: зовнішньополітична стратегія, принщипи зовнішньої політики, міжнародний тероризм, ядерна програма КНДР, російсько-американські відносини.

Прихід до влади у США республіканської адміністрації Д. Трампа у січні 2017 р. ознаменувався очікуваннями, як в академічному середовищі, так i в середовищі політичного істеблішменту, щодо різкої зміни акцентів зовнішньополітичної стратегії США. Виборча президентська кампанія у США 2016 p. супроводжувлась численними скандалами та різкими заявами кандидата від республіканської партії Д. Трампа щодо необхідності зміни курсу як внутрішньої, так і зовнішньої політики.

Д. Трамп представив своє бачення зовнішньої політики США, виступаючи у м. Вашингтон з нагоди впевненої перемоги на первинних виборах відразу в п'яти штатах країни.

Основний претендент на висунення кандидатом на посаду президента США від республіканців заявив у своїй програмній промові, що його головною метою буде реалізація принципу «Америка перш за все». Д. Трамп назвав зовнішню політику адміністрації діючого на той час президента США Б. Обами «повною і тотальною катастрофою» [1].

Значна частина програмного виступу була присвячена тому, що Д. Трамп назвав «слабкістю, безглуздістю і розбродом» в рядах адміністрації Б. Обами, які, за його словами, він сподівається ліквідувати. Д. Трамп пообіцяв аудиторії, що зібралася у Вашингтоні, «очистити зовнішню політику США від іржі, яка ऑii вкрила» [1].

У цьому контексті актуалізується питання щодо визначення новою президентською адміністрацією США стратегічних зовнішньополітичних настанов стосовно розбудови їх взаємовідносин 3 провідними центросиловими державами світу.

Окремі аспекти цього напряму наукових досліджень знайшли своє відображення у роботах вітчизняних науковців і зарубіжних дослідників. Серед робіт українських авторів необхідно відзначити аналітичні праці М. Рижкова, С. Шергіна, С. Федуняка, С. Галаки, Ю. Седляр, Л. Чекаленко, І. Дудко, О. Потєхіна, I. Погорської, Г. Перепелиці, М. Капітоненка тощо. Детермінуючі фактори щодо формування основних вимірів американсько-китайської взаємодії у контексті еволюції механізму міждержавних відносин представлені у роботах Зб. Бжезинського, Г. Кіссінджера, М. Фукса, К. Кала, Х. Брандса, М. Бота, Ф. Гайтіс. 
Наразі зовнішньополітична доктрина нової республіканської адміністрації знаходиться у стані розробки. Разом з тим, на сьогодні зважаючи на практичний вимір дій адміністрації президента США Д. Трампа на міжнародній арені можна протежити формування основних вимірів та меж втілення зовнішньополітичної стратегії.

20 січня 2017 р. новообраний президент США Д. Трамп проголосив інавгураційну промову. 3 тексту якої чітко викрасталізувався один 3 головних зовнішньополітичних пріоритетів - протиборство 3 ісламським тероризмом, зокрема Ісламською державою й міжнародним тероризмом в різноманітних формах і виявах [1]. Проте президентом США Д. Трампом не була чітко окреслена модель протидії тероризму, яка б відрізнялася від дій на цьому шляху попередньої демократичної адміністрації Б. Обами. Тези проголошені Д. Трампом у інавгураційній промові знайши продовження і в декларації «America First Foreign Policy» [2]. У документі підкреслювалось: «Адміністрація Д. Трампа прихильна зовнішній політиці, орієнтованій на американські інтереси і американську національну безпеку» [2]. Перемога над ІДІЛ та іншими радикальними ісламськими терористичними групами, проголошувалась у документі - найвищим пріоритетом зовнішньої політики нової адміністрації [2].

Наступним вектором зовнішньополітичної стратегії США за президенства Д. Трампа, який може бути чітко визначеним є відносини 3 КНР. Дії офіційного Пекіна у економічній сфері зазнали жорсткої критики 3 боку новообраного президента ще під час виборчої кампанії. Модернізація зовнішньополітичної риторики США викликала певне «охолодження» американсько-китайських відносин. Ще до офіційного вступу на посаду президента США дії Д. Трампа завдали чуттєвого удару щодо характеру взаємин у форматі Вашингтон-Пекін. 14 листопада 2016 р. відбулася телефонна розмова новообраного президента США Д. Трампа і лідера КНР Сі Цзіньпіном. Сторони обговорили розвиток відносин між Пекіном і Вашингтоном. За словами лідера КНР Сі Цзіньпіна, їх безупинний поступальний розвиток протягом майже 40 років пішов на користь американському і китайському народам. «Факти свідчать про те, що співпраця є єдиним правильним вибором щодо розвитку відносин КНР і США», - заявив голова КНР. Зі свого боку, новообраний президент США Д. Трамп погодився поважати «політику одного Китаю» [3].

Разом 3 тим, 2 грудня 2016 р. президент США Д. Трамп вперше за кілька десятиліть безпосередньо поговорив $з$ лідером Тайваню Цай Інвень, чим порушив дипломатичні домовленості з Китаєм.

Таким чином, це був перший офіційний контакт між представниками адміністрації Тайваню і президентом США починаючи з 1979 р.

Міністерство закордонних справ КНР заявило, що направило Д. Трампу офіційний протест у зв'язку 3 телефонною розмовою, яка відбулася між новообраним американським президентом та керівником Тайваню Цай Інвень. Пекін закликав США «ретельно і належним чином ставитися до тайваньського питання, щоб уникнути непотрібних ускладнень в американсько-китайських відносинах» [4].

Після 1979 року жоден лідер США, включаючи тих, що ще не вступили на посаду обраних президентів, ні разу не вступав в прямі контакти 3 керівниками Тайваню, уникаючи негативних наслідків для відносин з Пекіном. Однак Д. Трамп не тільки порушив це наявне протягом десятиріч негласне табу, якого неухильно 
дотримувалися як демократичні, так і республіканські адміністрації, але і не став приховувати факт своєї бесіди з Цай Інвень, двічі прокоментувавши його в Twitter.

Більш того, його записи ще більше загострили ситуацію. По-перше, в своїх коментарях Д. Трамп називає Цай Інвень «президентом Тайваню» (в Пекіні вважають таке визначення неприйнятним, використовуючи формулювання «регіональний лідер Тайваню»). По-друге, обраний президент США парирує звинувачення в тому, що він не повинен був говорити з Цай Інвень, дивуючись, чому цього не можна робити, якщо США постачають зброю Тайваню. «Цікаво: США продають Тайваню військову техніку на мільярди доларів, а я не повинен приймати вітальний дзвінок», - написав в Twitter Д. Трамп [3].

В інтерв'ю телеканалу Fox News президент США зазначив, що не вважає себе зв'язаним принципом «одного Китаю» [5].

Додатковим чинником, який роздмухував вогнище суперечностей в американсько-китайських відносинах стала заява держсекретаря США Р. Тіллерсона під час процедури затвердження його Сенатом: він заявив, що в разі призначення надішле Китаю сигнал, що йому буде закритий доступ до спірних островів у Південно-Китайському морі [6].

Китай відповів на слова держсекретаря США Р. Тіллерсона щодо островів у Південно-Китайському морі, зазначивши, що дії Пекіна носять законний характер. «Шо стосується Південно-Китайського моря, то Китай має повне право здійснювати будь-яку законну діяльність відповідно до свого суверенітету», заявив офіційний представник МЗС КНР Лу Кан [7].

Необхідно зазначити, що у липні 2016 р. міжнародний трибунал, створений за посередництва Постійної палати третейського суду в Гаазі постановив, що Китай не має історичних прав на спірні території в Південно-Китайському морі. Рішення було прийнято за скаргою Філіппін, які заявили, що дії КНР, чиї два патрульних катери наприкінці 2012 р. завадили філіппінській стороні заарештувати китайських рибалок, які ловили рибу неподалік від рифа Скарборо, порушують Конвенцію ООН з морського права 1982 року. Влада КНР заявила, що не збирається визнавати і виконувати рішення трибуналу.

Демонстрацією сили став похід авіаносця ВМС КНР «Ляонін» в супроводі п’яти кораблів, які пройшли водами спірного району Південно-Китайського моря. Подальший розвиток подій також мав характер загострення ситуації в акваторії Піденно-Китайського моря, у зв'язку з відмінними підходами адміністрації Д. Трампа і керівництва КНР до розв'язання териоріальних суперечностей. Зокрема, у грудні 2016 р. китайський корабель захопив американський підводний безпілотник. Новообраний президент США Д. Трамп, який на той час, ще не вступив на посаду досить жорстко прокоментував відвовідні дії КНР у Twitter: «Китай краде дослідний безпілотник ВМС США в міжнародних водах - вириває його з води і забирає в Китай. Безпрецедентний акт» [8].

Однією 3 детермінант американсько-китайських відносин є позиція США щодо ролі КНР у врегулюванні північнокорейської проблеми.

Президент США Д. Трамп заявив в інтерв'ю Financial Times, що в ході майбутніх переговорів з головою КНР Сі Цзіньпіном він має намір домагатися більш жорсткого підходу Пекіна до ракетно-ядерної проблеми КНДР [9]. «У Китаю $\epsilon$ можливості відчутного впливу на Північну Корею. I Китай може прийняти рішення надати нам допомогу з Північною Кореєю, або не надавати ії. Якщо Китай 
погодиться, це буде дуже добре для нього самого, якщо ні - добре нікому не буде», - зазначив президент США [9].

6-7 квітня 2017p. у США (штат Флорида) відбулася одна 3 найважливіших зустрічей президента США Д. Трампа - дводенний саміт 3 головою КНР Сi Цзіньпіном. Зустріч мала на меті узгодити наскільки це є можливим позиції сторін 3 питань торгово-економічних взаємовідносин, ситуації щодо ядерної програми КНДР й низки регіональних безпекових питань. За повідомленням ЗМІ КНР обидві сторони вважають саміт успішним [10].

Таким чином, для 45-го президента США порядок денний у взаємовідносинах з КНР визначається здатністю прагматичного поєднання політичних і економічних інтересів за умови уникнення «охолодження» чи різкого загострення відносин 3 Китаєм.

Наступною складовою зовнішньополітичного курсу адміністрації Д. Трампа $є$ змістовне наповнення відносин з європейськими союзниками. У своєму виступі на Брюсельському саміті НАТО, який відбувся 25-26 травня 2017 р. президент США Д. Трамп заявив лідерам країн НАТО, що вони повинні збільшити свої оборонні витрати як мінімум до 2\% ВВП, тоді як зараз лише п'ять 328 членів альянсу виконують це зобов'язання [11].

Крім того, лідер США неодноразово висловлювався проти планованого укладення угоди про вільну торгівлю між США і СС - Трансатлантичного торгівельного та інвестиційного партнерства.

Переформатування цілком можливе і щодо відносин США-СС. Зокрема в інтерв'ю британському журналу «Тhe Times» напередодні інавгураційної церемонії на посаду президента США Д. Трамп фактично підтримав референдум у Великій Британії щодо виходу зі складу СС, поставивши таким чином під сумнів майбутнє ЄC [12].

Надзвичайно важливим для нашої держави $\epsilon$ еволюція відносин між Вашингтоном і Москвою. Американсько-російські відносин були і $€$ однією 3 провідних тем світових мас-медіа починаючи з президентської виборчої кампанії у США. Ця тема супроводжувалась численними скандалами щодо російського впливу на перебіг і результат президентських виборів і загалом російської пристутності у системі прийняття зовнішньополітичних рішень США. Точками «накалу» у американсько-російських відносинах $є$ проблема Сирії, українське питання, позиція Росії щодо санкцій відносно КНДР тощо. Суттєве значення для визначення формату взаємин Вашингтон-Москва відіграватиме усвідомлення сприйняття керівництовм США зовнішньополітичних агресивних дій РФ, як відповідь на ігноруванння США інтересів Росії. У результаті цього цілкоми можлива тактика певних поступок у тактичних питаннях з боку Вашингтону, 3 тим, щоб перетворити РФ 3 держави-ревізіоніста на державу, яка своїми діями підтримуватиме існуючий міжнародний порядок. Проте, як стверджує журнал «Тһе Economist», аналізучи результати держсекретаря США Р. Тіллерсона до РФ у квітні 2017 р.: «Плани Д. Трампа щодо відносин 3 Росією зламалися швидше, ніж у попередників» [13]. Зокрема, погляди сторін на хімічні атаки в Сирії і російське втручання в американські вибори розійшлися. Сдине, про що вдалося домовитися це про створення двосторонньої групи для обговорення війн в Сирії і Україні, а також загроз з боку КНДР [13].

«Рівень довіри між нашими країнами найнижчий. Дві найбільші ядерні держави не можуть мати такі відносини», - підкреслив держсекретар США 
Р. Тіллерсон після зустрічі з головою російського МЗС С. Лавровим [15]. Разом 3 тим, необхідно не забувати, про наслідки дій попередньої адміністрації президента Б. Обами. Орієнтація на міжнародні інституції, правила і норми міжнародного порядку, і надзвичайно обережне застосування сили, дозволили агресору двічі перетнути «червоні маркери»: анексія Криму і агресія на сході України. Це стало викликом традиціоналізму у зовнішній політиці США щодо стримування експансіоністських заходів РФ на міжнародній арені. Окрім цього, дії РФ в Сирії, також засвідчили необхідність жорсткої риторики і використання силових засобів дипломатії (наразі економічних і демонстрації сили) адміністрацією Д. Трампа щодо РФ. Американські аналітики сподіваються, що, на відміну від попереднього президента США Б. Обами, президент Д. Трамп, як досвідчений перемовник, буде більше покладатися на силу. Для цього у нього є відповідні важелі - реальний стан речей у співвідношенні видатків на оборону, що був успадкований Д. Трампом. Так, у 2016 р. вони дорівнювали 611 мільярдів доларів, а це складає 36\% усіх світових воєнних видатків. КНР перебуває на другому місці з приблизно оціненим воєнним бюджетом у 215 мільярдів доларів. Росія перебуває лише на третьому місці із своїми 69,2 мільярдами доларів, хоча їі воєнні витрати у 2016 році виросли на 5,9\%. А вже ж коли порівнювати із 2007 роком (перед вторгненням до Грузіі), то воєнні видатки Росії виросли на цілих 87\%. На четвертому місці всесвітнього списку видатків на оборону в 2016 р. стояла Саудівська Аравія із 63,7 мільярдів доларів [15]. Проте, необхідно і враховувати, на які реальні поступки здатна, а головне прагне здійснити РФ 3 метою нормалізації відносин зі США та їх союзниками.

Отже, на сьогодні позиціонування США на міжнародній арені характеризується тенденцією до повернення лідерських позицій у розв'язанні найбільш складних міжнародних суперечностей, при цьому президент США Д. Трамп декларує необхідність перерозподілення відповідальності за міжнародну стабільність i дотримання норм міжнародного права 3 союзниками. Хоча, прагнення щодо збереження лідерських позицій у геополітичних реаліях XXI ст. визначає «приреченість» США на суттєво більші витрати, як економічні, політичні, так і військові з метою підтримання безпеки на регіональному та глобальному рівнях. Старший науковий співробітник Центру стратегічних i міжнародних досліджень США А. Галло, зазначає, що стратегія Д. Трампа на міжнародній арені визначається ескалацією в певних зонах, щоб змусити почати переговори там, де в іншому випадку їх учасники не захочуть сідати за стіл переговорів [16]. «Такий підхід може свідчити про доктрину «ескалації заради деескалації», - вважає А. Галло [16]. Таким чином, зовнішньополітична доктрина США наразі знаходиться у стані формування, але історичні традиції, політичний та економічний потенціал визначатиме збереження глобального впливу США, i за президенства Д. Трампа посилення силового чинника у зовнішньополітичних взаємовідносинах різнорівневих систем міжнародних відносин.

\section{Література}

1. Remarks of President Donald J. Trump. As Prepared for Delivery. Inaugural Address Friday, January 20, 2017. Washington, D.C. // The White House. [Electronic Resource] - Mode of Access: https://www.whitehouse.gov/inaugural-address (last access: 03.09.2017). - Title from the screen.

2. America First Foreign Policy // The White House. [Electronic Resource] - Mode of Access: https://www.whitehouse.gov/america-first-foreign-policy (last access: 01.10.2017). - Title from the screen. 
3. Landler M., Forsythe M. Trump Tells Xi Jinping U.S. Will Honor «One China» Policy // The New York Times 9 February 2017 [Electronic Resource] - Mode of Access: https://www.nytimes.com/2017/02/09/world/asia/donald-trump-china-xi-jinping-letter.html (last access: 18.09.2017). - Title from the screen.

4. Официальный представитель МИД КНР Гэн Шуан ответил на вопрос СМИ по поводу телефонного разговора между новоизбранным президентом США Д. Трампом и главой администрации Тайваня Цай Инвэнь // Ministry of Foreign Affairs, the People's Republic of China. [Електронний ресурс] Режим доступу: http://www.fmprc.gov.cn/rus/xwfw/fyrth/fyrbthdhdw/t1421265.shtml Дата звернення: 25.09.2017. Назва з екрану.

5. Bohan C., Brunnstrom D. Trump says U.S. not necessarily bound by «one China» policy // Reuters. [Electronic Resource] - Mode of Access: http://www.reuters.com/article/us-usa-trumpchina/trump-says-u-s-not-necessarily-bound-by-one-china-policy-idUSKBN1400TY (last access: 06.09.2017). - Title from the screen.

6. Brunnstrom D., Spetalnick M. Tillerson says China should be barred from South China Sea islands // Reuters. - 12 January 2017. [Electronic Resource] - Mode of Access: http://www.reuters.com/article/us-congress-tillerson-china-idUSKBN14V2KZ (last access: 10.10.2017). - Title from the screen.

7. Trump Abandons Trans-Pacific Partnership, Obama's Signature Trade Deal // The New York Times. - 23 January 2017. [Electronic Resource] - Mode of Access: https://www.nytimes.com/2017/01/23/us/politics/tpp-trump-trade-nafta.html (last access: 17.10.2017). Title from the screen.

8. Perlez J., Rosenberg M. China Agrees to Return Seized Drone, Ending Standoff, Pentagon Says // The New York Times. - 17 December 2016. [Electronic Resource] - Mode of Access: https://www.nytimes.com/2016/12/17/world/asia/china-us-drone.html?_r=0 (last access: 17.10.2017). Title from the screen.

9. Donald Trump: Without Twitter, I would not be here // FT interview. [Electronic Resource] Mode of Access: https://www.ft.com/content/943e322a-178a-11e7-9c35-0dd2cb31823a (last access: 25.10.2017). - Title from the screen.

10. США и Китай назвали встречу Трампа и Си Цзиньпина полезной // Interfax. - 8.04.2017. [Електронний ресурс] - Режим доступу: http://www.interfax.ru/world/557462 - Дата звернення: 17.09.2017. - Назва з екрану.

11. Diamond J. Trump scolds NATO allies over defense spending // CNN. [Electronic Resource] - Mode of Access: http://edition.cnn.com/2017/05/25/politics/trump-nato-financial-payments/index.html (last access: 26.10.2017). - Title from the screen.

12. Full transcript of interview with Donald Trump // The Times. [Electronic Resource] - Mode of Access: https://www.thetimes.co.uk/article/full-transcript-of-interview-with-donald-trump-5d39sr09d (last access: 26.10.2017). - Title from the screen.

13. Relations between America and Russia are at a low point // The Economist. [Electronic Resource] - Mode of Access: https://www.economist.com/blogs/democracyinamerica/2017/04/sobermoscow - (last access: 29.10.2017). - Title from the screen.

14. Прийом Тіллерсона у Москві цього тижня був зовсім не теплим // ZN. - 14.04.2017. [Електронний pecypc] - Режим доступу: https://dt.ua/WORLD/plani-trampa-schodo-vidnosin-zrosiyeyu-zlamalisya-shvidshe-nizh-u-poperednikiv-the-economist-239717_html - Дата звернення: 16.09.2017. - Назва з екрану.

15. Ткаченко В. США vs Росія: Новий початок чи продовження старих розбіжностей? // Укрінформ. - 22.09.2017. [Електронний ресурс] - Режим доступу: https://www.ukrinform.ua/rubricworld/2309202-ssa-vs-rosia-novij-pocatok-ci-prodovzenna-starih-rozbiznostej.html - Дата звернення: 16.10.2017. - Назва з екрану.

16. Rogin J. Trump's foreign policy doctrine: Escalate to de-escalate // Washington Post. [Electronic Resource] - Mode of Access: https://www.washingtonpost.com/opinions/globalopinions/trumps-foreign-policy-doctrine-escalate-to-de-escalate/2017/03/19/8cb897e0-0b35-11e7-a15fa58d4a988474_story.html?utm_term=.859626631d82 (last access: 26.10.2017). - Title from the screen.

\section{References}

1. REMARKS OF PRESIDENT DONALD J. TRUMP. AS PREPARED FOR DELIVERY. INAUGURAL ADDRESS (2017) The White House Washington, D.C. [Online] Available from: https://www.whitehouse.gov/inaugural-address [Accessed: $3^{\text {st }}$ September 2017]. 
2. AMERICA FIRST FOREIGN POLICY (2017) The White House Washington, D.C. [Online] Available from: https://www.whitehouse.gov/america-first-foreign-policy [Accessed: $1^{\text {st }}$ October 2017].

3. LANDLER M., FORSYTHE M. (2017) Trump Tells Xi Jinping U.S. Will Honor «One China». Policy The New York Time. 2 ${ }^{\text {nd }}$ September. [Online] Available from: https://www.nytimes.com/2017/02/09/world/asia/donald-trump-china-xi-jinping-letter.html [Accessed: $18^{\text {th }}$ September 2017].

4. OFYCYAL'NYJ PREDSTAVYTEL' MYD KNR HÈN SHUAN OTVETYL NA VOPROS SMY PO POVODU TELEFONNOHO RAZHOVORA MEZHDU NOVOYZBRANNYM PREZYDENTOM SSHA D. TRAMPOM Y HLAVOJ ADMYNYSTRACYY TAJVANJA CAJ YNVÈN' (2016) Ministry of Foreign Affairs, the People's Republic of China. 12 March. [Online] Available from: http://www.fmprc.gov.cn/rus/xwfw/fyrth/fyrbthdhdw/t1421265.shtml [Accessed: $25^{\text {th }}$ September 2017].

5. BOHAN, C., BRUNNSTROM, D. (2016) Trump says U.S. not necessarily bound by «one China» policy. Reuters. [Online] Available from: http://www.reuters.com/article/us-usa-trumpchina/trump-says-u-s-not-necessarily-bound-by-one-china-policy-idUSKBN1400TY $\quad\left[\right.$ Accessed: $6^{\text {th }}$ September 2017].

6. BRUNNSTROM, D., SPETALNICK, M. (2017) Tillerson says China should be barred from South China Sea Islands . Reuters. [Online] Available from: http://www.reuters.com/article/us-congresstillerson-china-idUSKBN14V2KZ [Accessed: 10 $0^{\text {th }}$ October 2017].

7. TRUMP ABANDONS TRANS-PACIFIC PARTNERSHIP, OBAMA'S SIGNATURE TRADE DEAL (2017) The New York Times. [Online] Available from: https://www.nytimes.com/2017/01/23/us/politics/tpp-trump-trade-nafta.html [Accessed: 17 ${ }^{\text {th }}$ October 2017].

8. PERLEZ, J., ROSENBERG, M. (2016) China Agrees to Return Seized Drone, Ending Standoff, Pentagon Says. The New York Times. [Online] Available from: https://www.nytimes.com/2016/12/17/world/asia/china-us-drone.html?_r=0 $\quad$ [Accessed: $17^{\text {th }} \quad$ October 2017].

9. TRUMP, D. (2017) Without Twitter, I would not be here. FT interview. [Online] Available from: https://www.ft.com/content/943e322a-178a-11e7-9c35-0dd2cb31823a $\quad$ [Accessed: $25^{\text {th }}$ October 2017].

10. SŠA Y KYTAJ NAZVALY VSTREČU TRAMPA Y SY CZYN'PYNA POLEZNOJ (2017) Interfax. [Online] Available from: http://www.interfax.ru/world/557462 [Accessed: $17^{\text {th }}$ September 2017].

11. DIAMOND, J. (2017) Trump scolds NATO allies over defense spending. CNN. [Online] Available from: http://edition.cnn.com/2017/05/25/politics/trump-nato-financial-payments/index.html [Accessed: $26^{\text {th }}$ October 2017].

12. FULL TRANSCRIPT OF INTERVIEW WITH DONALD TRUMP (2017) The Times. [Online] Available from: https://www.thetimes.co.uk/article/full-transcript-of-interview-with-donaldtrump-5d39sr09d [Accessed: $26^{\text {th }}$ October 2017].

13. RELATIONS BETWEEN AMERICA AND RUSSIA ARE AT A LOW POINT (2017) The Economist. [Online] Available from: https://www.economist.com/blogs/democracyinamerica/2017/04/sober-moscow [Accessed: $29^{\text {th }}$ October 2017].

14. PRYJOM TILLERSONA U MOSKVI C'OHO TYŽNJA BUV ZOVSIM NE TEPLYM (2017) ZN. [Online] Available from: https://dt.ua/WORLD/plani-trampa-schodo-vidnosin-z-rosiyeyuzlamalisya-shvidshe-nizh-u-poperednikiv-the-economist-239717_.html [Accessed: 16 ${ }^{\text {th }}$ September 2017].

15. TKACHENKO, V. (2017) SŠA vs Rosija: Novyj počatok čy prodovžennja staryx rozbižnostej? Ukrinform. [Online] Available from: https://www.ukrinform.ua/rubric-world/2309202-ssavs-rosia-novij-pocatok-ci-prodovzenna-starih-rozbiznostej.html [Accessed: $16^{\text {th }}$ October 2017].

16. ROGIN, J. (2017) Trump's foreign policy doctrine: Escalate to de-escalate. Washington Post. [Online] Available from: https://www.washingtonpost.com/opinions/global-opinions/trumps-foreignpolicy-doctrine-escalate-to-de-escalate/2017/03/19/8cb897e0-0b35-11e7-a15f-

a58d4a988474_story.html?utm_term $=.859626631 \mathrm{~d} 82$ [Accessed: $26^{\text {th }}$ October 2017].

Надійшла до редколегії 04.10.2017 
Olexander Shevchuk, Dr. habil. (Political Science), Professor, Dean of the Political Science Department of Petro Mohyla Black Sea National University, Mykolaiv

\title{
USA POSITIONING ON INTERNATIONAL ARENA DURING D. TRAMP'S PRESIDENCY: GLOBAL AND REGIONAL ASPECTS
}

\begin{abstract}
The article analyses the possible ways of transformation in US foreign policy during D. Trump's presidency. For now, the foreign policy doctrine of the new republican administration has not been yet established. Given the operational actions of administration, one can underline the following surveys and limits of their implementation in foreign policy strategy: 1. Confrontation with Islamic terrorism, in particular with the Islamic State and international terrorism in all its forms and actions. 2. Relations with People's Republic of China. The actions taken by the official Beijing in the sphere of economy have been criticized by the newly elected president even during his election campaign. One of the key determinants in Sino-American relations is position of the USA towards China in the regulation of the North Korean issue. 3. The informative fulfillment of relations with the European allies. In his speech during Brussels Summit of NATO (25-26 May 2017), Donald Trump declared that NATO members shall increase their defense costs to $2 \%$ GDP, while now only five of 28 Alliance members accomplish that requirement. However, the USA repeatedly speak out against planned agreement about free trade between the USA and the EU - the Transatlantic trade and investment partnership. 4. The evolution of relations between Moscow and Washington. "Hot spots》 of American-Russian relations are problems of Syria, Ukrainian issue, Russian position towards sanctions towards North Korea.
\end{abstract}

Key words: foreign policy strategy, principles of foreign policy, international terrorism, nuclear weapons program of DPRK, American-Russian relations. 